\title{
Costos asimétricos en empresas argentinas: análisis de modelos
}

\author{
Asymmetric Costs in Argentinian Businesses: Model Analysis \\ Custos assimétricos em empresas argentinas: análise de modelos.
}

\author{
Maciel Barbero \\ Universidad Nacional de Córdoba, \\ Córdoba, Argentina \\ E-mail:m8barbero@gmail.com
}

Fecha de recepción: 29/10/2019 Fecha de aceptación: 02/12/2019

\section{Resumen}

Este trabajo sigue, en sus primeras tres secciones, el trabajo de Banker y Bysalov (2014). Si bien se respeta el orden cronológico en que son presentados los temas, la estructura interna de cada sección fue modificada y se agregaron algunas aclaraciones que facilitan la comprensión de los mismos. Las referencias corresponden a los autores citados en el trabajo original.

Debido a que los costos son fundamentalmente los determinantes de las ganancias en las empresas, es necesario revisar como estos varían según sea el nivel de actividad. Además, los costos son determinantes/ condicionantes de la inversión y la competitividad de un país y tener conocimiento sobre cuáles son las causas de su comportamiento permitirá aportar información para que los tomadores de decisiones en las empresas tengan en consideración.

El comportamiento asimétrico de los costos implica que no siempre presentarán un comportamiento idéntico en sus magnitudes de ajuste cuando haya aumentos 0 caídas en las ventas.

Banker, Byzalov y Mashruwala (2014) sostienen que los administradores retienen recursos ociosos a pesar de que las ventas en los períodos anteriores fueron decrecientes. Se argumenta que los costos pegajosos 0 rígidos a la baja, uno de los posibles comportamientos asimétricos, surgen

Palabras clave - costos asimétricos - decisiones gerenciales

- ajuste de recursos porque ya existe una holgura de recursos 0 capacidad instalada y existe además un costo presente o futuro si se quiere realizar un ajuste hacia la baja en esos recursos ociosos. 
Banker, Byzalov y Chen (2013) argumentan que uno de los determinantes principales de los costos asimétricos es la magnitud de los costos de ajuste de los recursos.

La investigación analiza si existe un comportamiento asimétrico de los costos en empresas argentinas listadas en el Mercado de Valores para el período de análisis 2002-2012. Para ello, se comparan distintos modelos con distintas hipótesis implícitas.

\section{Abstract}

The first three sections of this research are based on the work of Banker and Bysalov (2014). Even though the chronological order of the topics was maintained, the internal structure of each section was changed and some explanations were added in order to enhance the readers' understanding. The references herein cited correspond to the original work.

Since the profits of a business are determined by costs, it is necessary to analyze their variations at different activity levels. Moreover, costs determine the investment and competitiveness of a country. If the reasons for their behavior are clear, businesses will be able to make wellfounded decisions. The asymmetric behavior of costs means that these will not always behave identically when adjustments are applied in a sales increase or decrease.

Banker, Byzalov and Mashruwala (2014) state that managers keep idle resources in spite of decreasing sales during previous periods. The authors argue that downward rigid costs or sticky downward, -one of the possible asymmetric behaviors - are the result of the existence of more than enough resources or a sufficient productive capacity, and that adjusting those idle resources with a downward trend implies a present or future cost.

Banker, Byzalov and Chen (2013) argue that the magnitude of the adjustment costs of resources is one of the major determinants of asymmetric costs.

This research work studies whether costs in the Argentinian businesses

Keywords - asymmetric costs - management decisions - resources adjustment listed in the stock market show an asymmetric behavior over the period 2002-2012. To this end, different models with different implicit hypotheses are compared.

\section{Resumo}

Este trabalho segue, em suas primeiras três seções, o trabalho de Banker e Bysalov (2014). Mesmo que respeita-se a ordem cronológica em que são apresentados os temas, a estrutura interna de cada seção foi modificada e acrescentaram-se alguns esclarecimentos que facilitam a compreensão dos mesmos. As referências correspondem aos autores citados no trabalho original. 
Devido a que os custos são fundamentalmente os determinantes dos lucros nas empresas, é necessário revisar como estes variam conforme 0 nível de atividade. Aliás, os custos, são determinantes/condicionantes do investimento e da competitividade de um país e, ter conhecimento sobre quais são as causas de seu comportamento, permitirá contribuir com informação útil para a tomada de decisões nas empresas.

0 comportamento assimétrico dos custos implica que, os mesmos, nem sempre apresentarão um comportamento idéntico em suas magnitudes de ajuste quando tenha aumentos ou quedas nas vendas.

Banker, Byzalov e Mashruwala (2014) sustentam que os administradores retêm recursos ociosos apesar de que as vendas nos períodos anteriores foram decrescentes. Argumenta-se que os custos pegajosos ou rígidos à baixa, um dos possíveis comportamentos assimétricos, surgem porque já existe uma folga de recursos ou capacidade instalada e existe aliás um custo presente ou futuro se quer se realizar um ajuste para à baixa nesses recursos ociosos.

Banker, Byzalov e Chen (2013) argumentam que um dos determinantes principais dos custos assimétricos é a magnitude dos custos de ajuste dos recursos.

Palavras-chave

- custos assimétricos

- decisões gerenciais

- ajustamento de recursos

A pesquisa analisa se existe um comportamento assimétrico dos custos em empresas argentinas listadas no Mercado de Valores para o período de análise 2002-2012. Para isso, comparam-se diferentes modelos com diversas hipóteses implícitas. 